\title{
Physicochemical properties of water quality of Imeh, Edegelem and Chokocho communities located along Otamiri-oche River in Etche Ethnic Nationality of Rivers State, Nigeria
}

\author{
*ONYEGEME-OKERENTA BM; OBIA C., WEGWU MO ${ }^{1}$ \\ Department of Biochemistry, Faculty of Sciences, University of Port Harcourt, Rivers State, Nigeria \\ *Corresponding Author: e-mail: blessing.onyegeme-okerenta@uniport.edu.ng \\ Tel: +234 (0)8035201039
}

\begin{abstract}
Some physiochemical properties of water quality of Otamiri-oche River which runs through Imeh, Edegelem and Chokocho Communities in Etche ethnic nationality of Rivers State, Nigeria were investigated. Samples were collected in triplicate from the three different locations along the river in both rainy and dry seasons. Each sampling points is located $500 \mathrm{~m}$ away from the successive one, and the samples were taken from the open river at the zone extending beyond the shoreline. Samples were stored in ice packs and immediately taken to the laboratory to investigate some selected physico-chemical characteristics. Also, bacteriological study was carried out on the samples. The laboratory results of the selected physico-chemical parameters when compared with the world health organization (WHO) standard showed that all the selected physico-chemical parameters were within the world health organization (WHO) permissible in both rainy and dry season except $\mathrm{pH}$. For rainy season, the $\mathrm{pH}$ values were $5.00 \pm 0.00,5.40 \pm 0.40$, and $5.40 \pm 0.30$ for Imeh, Edegelem and Chokocho respectively. For the dry season, the $\mathrm{pH}$ values were $5.83 \pm 0.01,5.56 \pm 0.01,5.90 \pm 0.01$ for Imeh, Edegelem and Chokocho respectively. Also magnesium hardness exceeded the World Health Organization (WHO) permissible limit in rainy season only. The results of bacteriological study showed that all the sampling locations contained high numbers of coliform bacteria in both rainy and dry seasons. The number of coliform bacteria during rainy season was $25.00 \pm 0.00,25.00 \pm 0.00$, and $35.00 \pm 0.00$ for Imeh, Edegelem and Chokocho respectively. Those of dry season were 93.00 $\pm 3.55,56.66 \pm 4.49$, and $35.60 \pm 4.17$ for Imeh, Edegelem and Chokocho respectively. The difference between the rainy and dry season was tested statistically using the t-test. The results of the statistical analyses showed a significant difference $(\mathrm{p}<0.05)$ between the rainy and dry seasons. ( JASEM
\end{abstract}

http://dx.doi.org/10.4314/jasem.v20i1.14

KEYWORDS: River, physico-chemical parameters, $\mathrm{pH}$, rainy and dry seasons

\section{Introduction}

Water is the most valuable natural resource available to man, without which no life can survive. Therefore, adequate and safe water supply is a pre-requisite for significant socio-economic development of any community (Algaon-odot et al., 2012). Water bodies' pollution is the introduction of contaminants into water bodies. Water pollutants are directly or indirectly discharged into water bodies without adequate treatment to remove harmful substances (Michael Hogan, 2014). Water pollution affects plants and animals living in these water bodies, and also, affects other aquatic biota. Globally, the most prevalent water quality problem is eutrophication -the introduction of nutrients (mainly phosphates and nitrates) into water bodies. Eutrophication substantially impairs beneficial uses of water (UNDESA, 2105)

Water quality refers to the chemical, physical, biological, and radiological characteristics of water (Dier song et al., 2009). It is a measure of the conditions of water relative to the requirement of one or more biotic species, and or to any human need or purpose. It is most frequently used by reference to a set of standards against which compliance can be assessed. The most common standards used to access water quality relate to health of ecosystems, safely of human contact and consumption (USEPA, 2005).

Water quality parameters are parameters in which the assessment of water quality is based. Water quality parameters are divided into three categories; physical parameters, chemical parameters and biological parameters (Ben-coker, 2012). Some of the physicochemical parameters include turbidity, temperature, electrical conductivity (EC), total suspended solids (TSS), pH, dissolved oxygen (DO), nitrates, nitrites, phosphates, biochemical oxygen demand (BOD), etc. Water is adjudged safe if these parameters fall within certain range that is tolerable by human when consumed; and also tolerable by living organism within the aquatic environment (Standard organization of Nigeria, 2007). Water quality standard or guideline describes the quality parameters set for drinking water (Arokoya et al., 2014). Despite 
the truism that every human on this planet needs water to survive, and that water may contain many harmful constitutions, there is no universally recognized or acceptable international standard for drinking water.

Even where standards do exist, and are applied, the permitted concentration of individual constituents may vary by as much as ten times from one set of standards to another. Many developed countries specify standards to be applied in their own country. In Europe, this includes the European Drinking water directives; and in U.S.A, the United States Environmental Protection Agency (Arokoyu et al., 2004).

Surface water is an essential and vital resource for the people of Niger Delta. It is a major source of water for drinking and manufacturing, especially during the dry season when public water supply is irregular (Arimieari et. al., 2005). The research was carried out on Otamiri-oche River in Etche ethnic nationality of Rivers State, Nigeria and the aim is to investigate the surface quality of Otamiri-oche River in Etche ethnic nationality of Rivers State, Nigeria. Etche ethnic nationality is one of the minority ethnic groups in Nigeria. It is bounded on the north by Imo state and on the south by Obio/Akpor local government area of Rivers State. It is bounded on the east by Abia State and Oyigbo local government area of Rivers State, and on the West by Ikwerre local government area of Rivers State (Patric, 1999). The Otamiri-oche River originates from Imo state, and flows via several communities Imo State to Ozuzu in Etche. From Ozuzu it crosses several villages and towns within the North-western and south-western parts of Etche to empty into the popularly called Imo River just at the boundary between Rivers and Abia State (Patric, 1999).

\section{Methodology}

Sample Collection: Water samples were collected in triplicate from three different sampling locations along the Otamiri-oche River in both rainy and dry seasons. The sampling locations were Imeh, Edegelem, and Chokocho water fronts. Each location is about $500 \mathrm{~m}$ away from the one next to it. At the time of sample collection, each sample bottle was held at the base while a gloved hand was use to uncover the bottle. The bottle was them immersed to about $30 \mathrm{~cm}$ below, with its mouth in upstream direction. The sample bottles were tightly covered and were immediately sent to the laboratory for analysis.

Analysis of Samples: Standard analytical procedures were used in the determination of selected physical, chemical and biological water quality parameters of the samples. Selected physico-chemical analysis such as $\mathrm{pH}$, temperature, turbidity, electrical conductivity (EC), total suspended solids (TSS), Nitrites, Nitrates, total hardness, Magnesium hardness, Chlorides, dissolved $\mathrm{CO}_{2}$, etc. were carried out. The $\mathrm{pH}$ of the samples was measured using probe and electronic $\mathrm{pH}$ meter (Jaiswal, 2003). Turbidity and total suspended solids were measured using turbidometer. Electrical conductivity was measured with conductivity meter while nitratest and nitrical methods were used to measured nitrates and nitrites respectively (Monica, 2006).

Dissolved $\mathrm{CO}_{2}$ and total hardness were measured using titration method whereas chloride was measured using DPD colorimeter. Bacteriological study was done using multiple tubes/ most probable number method.

Statistical Analysis: Descriptive statistics, as well as T-test were used to statistically analyze the data generated from laboratory investigation.

\section{RESULT AND DISCUSSION}

The results of the physical, chemical and microbiological analysis carried out on the various water samples are shown in tables 1 and 2 , and figures 1 to 5. All the tested physico-chemical properties of the samples drawn from the three locations during rainy season were within the world health organization (WHO) permissible limit for drinking water except the $\mathrm{pH}$ and magnesium hardness (Table 1). The mean $\mathrm{pH}$ values are $5.9 \pm 0.00,5.40 \pm 0.40$, and $5.40 \pm 0.30$ for Imeh, Edegelem, and Chokocho respectively. The mean values for magnesium hardness are 20.50 \pm 0.30 for

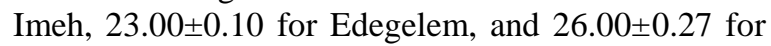
Chokocho. Also the bacteriological analyses revealed that samples drawn from the three locations during the rainy season contained high number of coliform bacteria. Their mean values are 25.00 \pm 0.00 , $25.00 \pm 0.00$ and 35.00 \pm 0.00 for Imeh, Edegelem, and Chokocho sampling locations respectively. 
Table 1: Physico-chemical and bacteriological quality of Otamiri-oche River during rainy season

\begin{tabular}{clcccc}
\hline S/N & \multicolumn{1}{c}{ Parameter } & \multicolumn{3}{c}{ Sampling Point } & WHO \\
\cline { 3 - 5 } & & Chokocho & Edegelem & Imeh & \\
\hline 1 & Turbidity (NTU) & $15.5 \pm 0.21^{*}$ & $10.07 \pm 0.01^{*}$ & $13.00 \pm 1.16^{*}$ & 5 \\
2 & EC $(\mu \mathrm{S} / \mathrm{cm})$ & $17.24 \pm 0.05$ & $22.30 \pm 0.20$ & $22.50 \pm 0.17$ & 1000 \\
3 & $\mathrm{pH}$ & $5.40 \pm 0.30^{*}$ & $5.40 \pm 0.40^{*}$ & $5.90 \pm 0.00^{*}$ & $6.5-8.5$ \\
& & $92.30 \pm 0.76$ & $99.40 \pm 0.40$ & $92.50 \pm 2.00$ & 250 \\
4 & Chloride (mg/L) & $76.00 \pm 1.00$ & $56.00 \pm 5.20$ & $65.00 \pm 0.00$ & 500 \\
5 & Total Hardness (mg/L) & $26.00 \pm 0.27^{*}$ & $28.00 \pm 0.1^{*}$ & $20.50 \pm 0.30^{*}$ & 20 \\
6 & Mg hardness (mg/L) & $0.02 \pm 0.02$ & $0.02 \pm 0.01$ & $0.03 \pm 0.03$ & 0.3 \\
7 & Total iron (mg/L) & $30.00 \pm 5.00$ & $32.00 \pm 6.7$ & $30.00 \pm 22.90$ & 400 \\
8 & Sulphate (mg/L) & $0.04 \pm 0.01$ & $0.04 \pm 0.03$ & $0.02 \pm 0.01$ & 0.05 \\
9 & Saline \& free & $2.60 \pm 0.00$ & $2.9 \pm 0.00$ & $3.00 \pm 1.00$ & 10 \\
10 & Nitrate (mg/L) & $0.012 \pm 0.00$ & $0.008 \pm 00$ & $0.005 \pm 0.00$ & 1.0 \\
11 & Nitrite (mg/L) & $8.66 \pm 0.03$ & $11.50 \pm 00$ & $10.35 \pm 0.98$ & 1000 \\
12 & TSS (mg/L) & $8.80 \pm 0.47$ & $8.80 \pm 00$ & $8.50 \pm 0.0$ & \\
13 & Free CO $(\mathrm{mg} / \mathrm{L})$ & $35 \pm 0.00^{*}$ & $25 \pm 0.00^{*}$ & $25 \pm 0.00^{*}$ & 0 \\
14 & Coliform & (Mpn/100ml) & & & 0 \\
\hline
\end{tabular}

$*=$ Significant values $(\mathrm{p}<0.05) \quad$ Values are expressed as mean \pm SD

Table 2 shows the physico-chemical and the bacteriological properties of Otamiri-oche River during the dry season. Form the table, all the tested physic-chemical parameters were within the world health organization (WHO) permissible limit except the $\mathrm{pH}$ whose mean values are; $5.83 \pm 0.0,5.56 \pm 0.01$, and 5.91 \pm 0.01 for Imeh, Edegelem and Chokocho respectively. Also the bacteriological analysis showcased the presence of high number of coliform bacteria with mean values of 9.300 $\pm 3.55,56.66 \pm 4.49$,

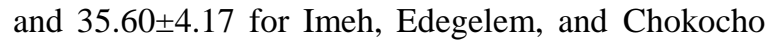
respectively. The difference between the values of the rainy season and those of the dry season was statistically significant ( $\mathrm{p}>0.05)$.

Table 2: Physico-chemical and bacteriological quality of Otamiri-oche River during dry season

\begin{tabular}{|c|c|c|c|c|c|}
\hline \multirow[t]{2}{*}{$\mathbf{S} / \mathbf{N}$} & \multirow[t]{2}{*}{ Parameters } & \multicolumn{3}{|c|}{ Sampling Point } & \multirow[t]{2}{*}{ WHO } \\
\hline & & Chokocho & Edegelem & Imeh & \\
\hline 1 & Turbidity (NTU) & $9.80 \pm 0.01 *$ & $6.98 \pm 0.03 *$ & $9.84 \pm 0.01 *$ & 5 \\
\hline 2 & $\mathrm{EC}(\mu \mathrm{S} / \mathrm{cm})$ & $20.22 \pm 0.02$ & $23.32 \pm 0.02$ & $21.81 \pm 0.01$ & 1000 \\
\hline 3 & $\mathrm{pH}$ & $5.56 \pm 0.01 *$ & $5.91 \pm 0.01 *$ & $5.83 \pm 0.01 *$ & $6.5-8.5$ \\
\hline 4 & Chloride (mg/L) & $36.92 \pm 0.01$ & $46.56 \pm 0.01$ & $44.74 \pm 0.01$ & 250 \\
\hline 5 & Total Hardness (mg/L) & $20.01 \pm 0.01$ & $70.02 \pm 0.01$ & $16.01 \pm 0.01$ & 500 \\
\hline 6 & Mg hardness (mg/L) & $10.01 \pm 0.01$ & $7.21 \pm 0.01$ & $4.02 \pm 0.02$ & 20 \\
\hline 7 & Total iron $(\mathrm{mg} / \mathrm{L})$ & $0.02 \pm 0.01$ & $0.02 \pm 0.01$ & $0.02 \pm 0.01$ & 0.3 \\
\hline 8 & Sulphate $(\mathrm{mg} / \mathrm{L})$ & $11.87 \pm 0.01$ & $16.91 \pm 0.01$ & $17.82 \pm 0.02$ & 400 \\
\hline 9 & Saline \& free $\mathrm{NH}_{3}(\mathrm{mg} / \mathrm{L})$ & $0.06 \pm 0.01 *$ & $0.06 \pm 0.01 *$ & $0.05 \pm 0.01$ & 0.05 \\
\hline 10 & Nitrate (mg/L) & $0.012 \pm 0.01$ & $0.24 \pm 0.01$ & $0.20 \pm 0.01$ & 10 \\
\hline 11 & Nitrite (mg/L) & $0.01 \pm 0.01$ & $0.04 \pm 0.01$ & $0.02 \pm 0.01$ & 1.0 \\
\hline 12 & $\mathrm{TSS}(\mathrm{mg} / \mathrm{L})$ & $10.22 \pm 0.01$ & $11.92 \pm 0.02$ & $10.52 \pm 0.02$ & 1000 \\
\hline 13 & Free $\mathrm{CO}_{2}(\mathrm{mg} / \mathrm{L})$ & $8.82 \pm 0.02$ & $8.82 \pm 0.02$ & $8.82 \pm 0.02$ & \\
\hline 14 & Coliform $(\mathrm{Mpn} / 100 \mathrm{ml})$ & $56.66 \pm 4.49 *$ & $35.60 \pm 4.17 *$ & $93.0 \pm 3.55^{*}$ & 0 \\
\hline
\end{tabular}




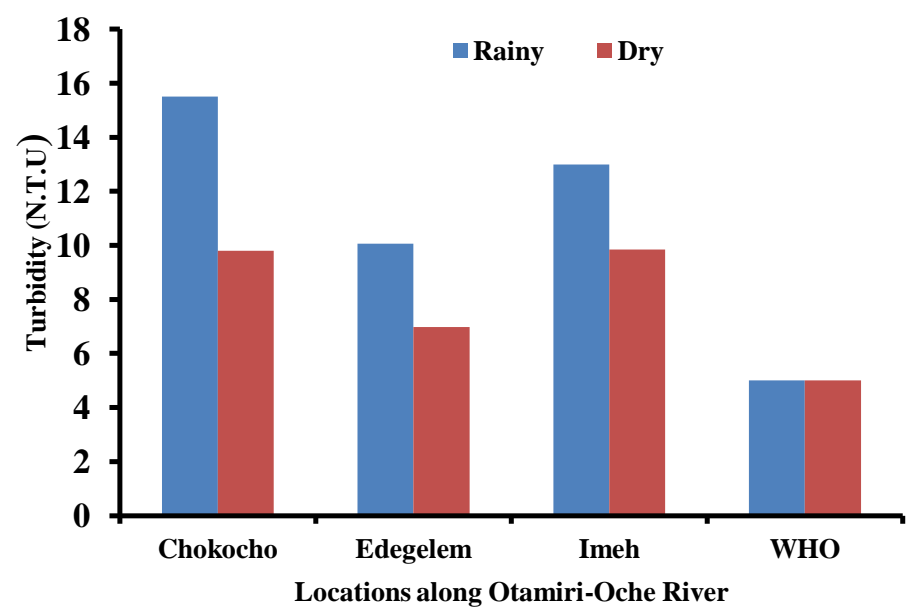

Fig 1: Turbidity values of Chokocho, Edegelem and Imeh Communities located along Otamiri-oche River during rainy and dry seasons

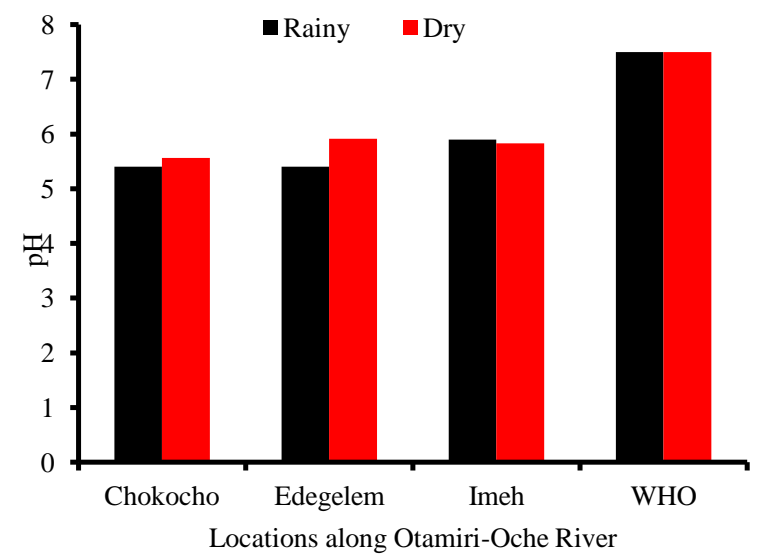

Fig 2: pH measure of Chokocho, Edegelem and Imeh Communities located along Otamiri-oche River during rainy and dry seasons

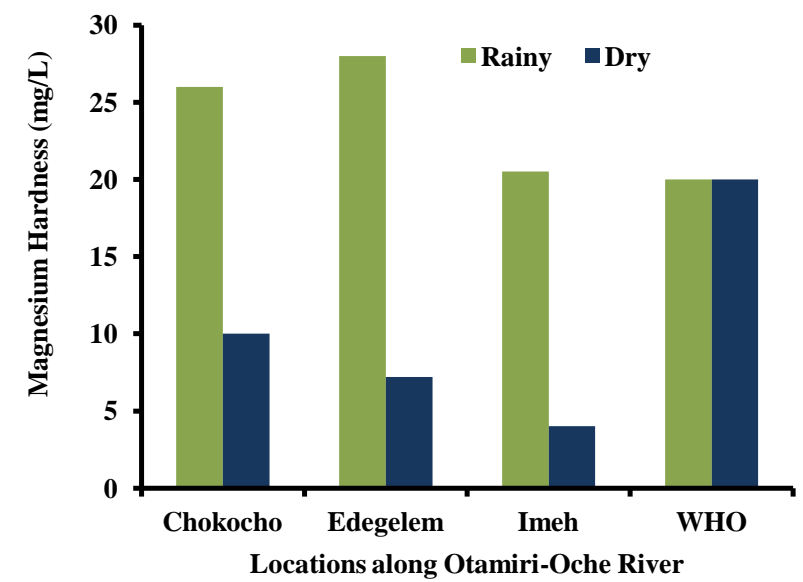

Fig 3: Magnesium concentration of Chokocho, Edegelem and Imeh Communities located along Otamiri-oche River during rainy and dry seasons 


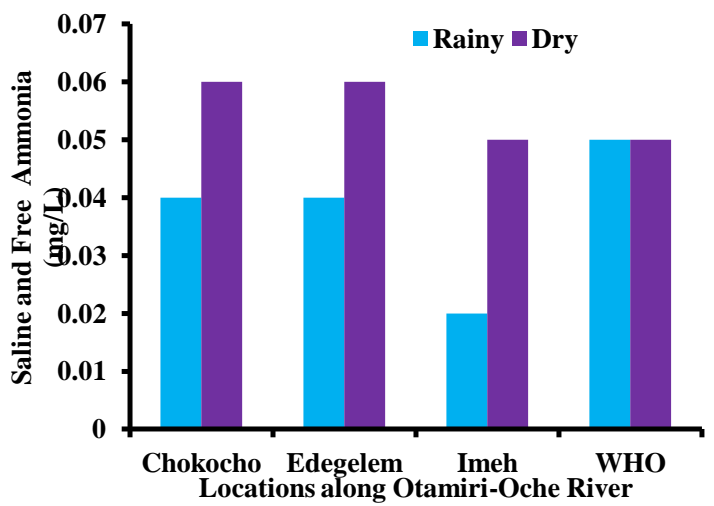

Fig 4: Saline and Free Ammonia concentration of Chokocho, Edegelem and Imeh Communities located along Otamiri-oche River during rainy and dry seasons

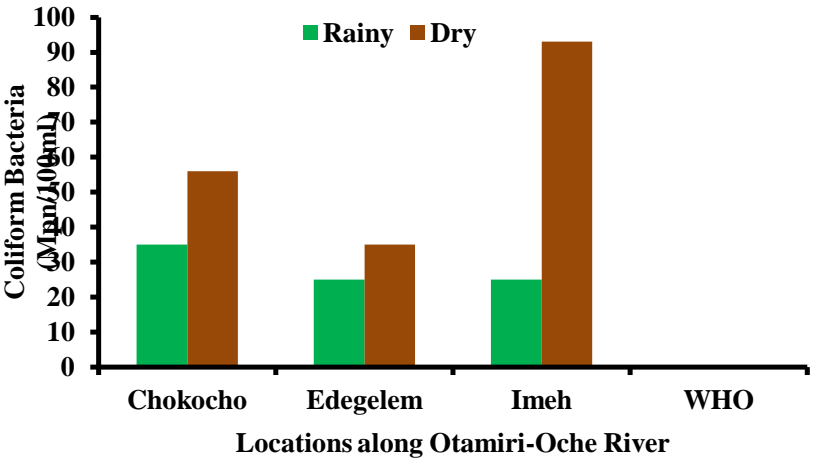

Fig 5: Total Coliform count of Chokocho, Edegelem and

Imeh Communities located along Otamiri-oche River during rainy and dry seasons

Turbidity values obtained for Chokocho, Edegelem and Imeh locations were higher during the rainy season than the dry season. Chokocho and Imeh had significantly higher values than Edegelem. However, values of the three locations measured during the rainy and dry seasons were significantly higher $(\mathrm{p}<0.05)$ when compared with the WHO standard limit for drinking water. This may probably be due to effluent of industrial wastes from dredging companies into Otamiri-oche River. According to Okeke and Adinna (2013), solid waste material and soil particles transported by runoff from urban activities into the river may increase the turbidity of the river. Turbidity affects fish and aquatic life by interfering with sunlight penetration. Park (2009) is of the view that drinking water should be free from turbidity on aesthetic grounds.

Magnesium concentration of Chokocho and Edegelem locations were significantly higher $(p<0.05)$ than Imeh location and WHO standard limit for drinking water during the Rainy season than the dry season. However, a significant decrease $(\mathrm{p}<0.05)$ in $\mathrm{Mg}^{2+}$ concentration was observed in Chokocho, Edegelem and Imeh sampling locations when compared to the WHO standard limit for drinking water. Magnesium concentration measures the hardness of water. Therefore high $\mathrm{Mg}^{2+}$ concentration obtained during the rainy season may suggest water hardness. According to Onojake and Abrakasa (2012), the hardness of natural waters mainly depends on the presence of dissolved calcium and magnesium salts which are sources of pollution on water bodies, and the positive loading on total hardness which includes $\mathrm{Mg}^{2+}$ hardness, $\mathrm{Ca}^{2+}$ hardness, signifies the contribution from industrial discharges.

Saline and Free Ammonia concentration of Chokocho and Edegelem locations were significantly higher $(p<0.05)$ than Imeh location and WHO standard limit for drinking water during the dry season than the rainy season. However, a significant decrease $(p<0.05)$ in Saline and Free Ammonia concentration was observed in Chokocho, Edegelem and Imeh sampling locations during the rainy season when compared to the WHO standard limit for drinking water. According to Technical Bulletin, (2000), Ammonia is rarely found in unpolluted surface water or well water, but water contaminated with sewage, animal wastes or fertilizer runoff may contain elevated levels. Human beings and higher animals are less sensitive to ammonia in water, but long-term ingestion of water containing more than $1 \mathrm{mg} / \mathrm{l}(\mathrm{ppm})$ ammonia may be damaging to internal organ systems. Also, Ammonia is toxic to fish and that the toxicity increases with increasing $\mathrm{pH}$ and temperature of the water. In enclosed circulating aqua cultural systems, ammoniacal nitrogen produced by the decomposition of excrement and unused food is one of the leading causes of disease and mortality in fish (WQA 2013) 
Water is the source of life and human civilization has become one of the major issues in recent years. Adequate and safe water supply is a therefore, a prerequisite for significant socio-economic development of any community (Akpan-Idot et al., 2012). The results of this research have revealed that Otamirioche River contains high number of coliform bacteria. This could be attributable to indiscriminate and illegal discharge of untreated domestic sewage into the river. The presence of coliform bacteria in any water body renders it unfit for human consumption (WHO, 1999). The presence of coliform bacteria in Otamiri-oche River is an index of the presence of other pathogenic microbes in the river. This result agrees with the report of Akpan-Idot et al. (2012); their study revealed that Okpauku River in Yala, Cross River State contains high number of coliform bacteria.

The results further showed that the $\mathrm{pH}$ of Otamirioche River in both rainy and dry seasons were low, pointing to the fact that the river is acidic. Build-up of organic refuse in the river could be tied to its acidic nature. This is because, the degradation of organic wastes by aerobic microbes produces carbon dioxide as a by-product, carbon dioxide then dissolves in water to yield carbon acid, hence, increasing the acidity of the water (Keith, 2013). Therefore, the acidic nature of Otamiri-oche River might threaten its endemic species.

In conclusion, the results of analysis of water quality carried out on Imeh, Edegelem and Chokocho Communities located along Otamiri-oche River in Etche ethnic nationality of Rivers State in both rainy dry rainy seasons showed that the river is not a suitable source of drinking water. It has been polluted mainly by fecal materials and other organic wastes.

\section{REFERENCES}

Akpan - Idot, A. U., Ibrahim, A. \& Udo, J. A. (2012). Water Quality assessment of Okpauku Otamirioche River for Drinking and Irrigation uses in Yala Cross Otamiri-oche River State, Nigeria. Research Journal of Environmental Science, Vol. 6(2) pp 210-221.

Arimieari, L.W., Sangodoyin, A. Y. \& Ereoforiokuma, N. S. (2014). Assessment of Surface Water Quality in Some Selected Locations in Port Harcourt. Nigeria International Journal of Engineering Research \& Technology (IJERT), 3(7), pp 1146-1151.

Arokoyu, S. B. \& Ukpere, D. R. (2014). Access to safe water supply and sanitation in lower Orashi Otamiri-oche River basin, Rivers State, Nigeria. ARPN Journal of science and technology,4,1-3.
Baron, S. A., Rhanalaker, S. A. \& Mulley, D. V. (2007). Analysis of Water Quality; Using Physio-Chemical Parameters, Jandal Jank in Kohapar District, Maharashra International Journal of Advanced Biotech and Research. Vol. 1 (2) pp 1-4.

Ben-Coker, M. O. (2012). Effect of Slaughter house discharge on Water Quality of Ikpoba River, Nigeria. Bioscene Technology, 52 (1) pp 1-4

Bryl Edison, Hodgson, K. \& Manu, L. (2006). Drinking Water Quality Framework for South Africa. Water South Africa, Vol. 32 (5), pp 673 678

Chris Kreger, Ambrose, S. H., Easselt, T. J., Bowen, D. N., Johnsni, D. N., Lamb, P., Saul, M. \& Winter, N. (2010). Meaning of Environmental Terms. Journal of Environmental Quality. 26, $581-589$.

Diersong, N. (2009). Water Quality; Frequently Asked Questions. Florida Brooks National Marine Sanctuary, Key West. pp. 1-2.

Etim, E. E., Odoh, R., Itodo, A. U., Umoh, S. D. \& Lawal, U. (2013). Water Quality Index for different sources in the Niger Delta Region of Nigeria. Frontiers in Science Vol. 3 (3), pp 1-2.

Franson, Mary Ann. (1975). Standard Methods for the Examination of Water and Waste Water, $4^{\text {th }}$ Edition. Amarican Public Health Association, pp $078-8$

Ganoulis, Jacques (2009). Risk analysis of water pollution. Wiely-Blackwell pub Ltd, 1-4.

Jaiswal, P. C. (2003). Soil, Plant and Water Analyses. Kalyani Publishers Ludhiana, New Delhi Norda Hyderabab, India. Pp. 1 - 399.

Jay, M. O., Banigbo, O., Odukoya, O. O. \& Arowolo, T. A. (2007). Water Quality Assessment of Ogun River, South West Nigeria. Journal of Environmental Monitoring and Assessment Vol. 133 (3): 473-482.

Joel, E. E., Russel, K. M., Dianne, E. \& Anne, A. (2002). Water Quality Assessment of Four Inter Mutent Streams in Los Almos, New Mexico. New Mexico Environment Department. Surface Water Quality Bureau, New Mexico. pp 1-2.

Keith Bellinghan. (2003). Physiochemical parameters of water. $2^{\text {nd }}$ edition, Oxford University press,36.

limgis, A., Entasuanensal, R. E. \& Degraft-Johnson, A. A. (2001). Assessment of Water Quality of 
the Rivers in Ghana. West African Journal of Applied Ecology, Vol, 15, pp 1-2.

Linsley R. K. \& Franzini, J. B. (1972). Water Resources Engineering McGraw Hill, pp. 454456.

Mana, A. G., Tam, C. C., Higgins, C. D. \& Rodriguez, L. C. (2007). The Association between Water Quality, turbidity and Gastrointestinal Disease, a Systematic Review BMC, Public Health Vol. 7 (256), pp 1.

Monica Cheesbrough. (2006). Laboratory practice in tropical countries. $2^{\text {nd }}$ edition, Cambridge university press, 146-153.

Moshod, K. P. (2008). Assessment of Water Quality and Its Indigenous Clarian Ganepinus Fish in Asa River, Nigeria. International Journal of Environmental Republic Health Vol. 8 (2) pp 12.

Okeke, P. N. \& Adinna, E. N. (2013). Water Quality Study of Otamiri Otamiri-oche River in Owerri, Nigeria. Universal Journal of Environmental Research and Technology, 3(6) pp 641-649.

Olatunji, M. K.; Kolawole, T. A; Albert, B. O. \& Anthony, I. O. (2011). Assessment of water quality in Asa Otamiri-oche River (Nigeria) and its indigeneous clarias Gariepinus fish. International journal environ, Res. Public Health. 8(11): $4332-4335$

Omole, D.O. \& Longer, E.O. (2008). An Assessment of Imp of Abattoir Effluents on Otamiri-oche River Illo, Ofa, Nigeria. Journal of Environmental Science and Technology. Vol (2) pp 54-56.

Onojake, M. C. \& Abrakasa, S. (2012). Multivariate Statistical Analysis on Pollution Level of Woji Otamiri-oche River in Port Harcourt, Nigeria. International Journal of Environment and Bioenergy, 2(1): 43-52
Park, K. (2009). Park's Textbook of Preventive and Social Medicine. India, M/S Banarsidas Bhanot Pub, pp. 659-661. Servicon Services.

Patric Naagbanton. (1999). Shell toxic war against Umuakuru - Igbo people. Environmental Right Action (ERA). 3 - 4.

Technical Bulletin, Oregon Department of Human Services (2000). Health Effects Information: Ammonia. Environmental Toxicology Section. pp $2-3$

Tubonimi, K. J., Omubo, A. \& Hebert, O. S. (2010). Assessment of Water Quality Along Amadi Creek Port Harcourt, Nigeria. Science Africa, Vol. 9 (1) pp $150-152$.

United Nation Development of Economic and Social Affairs (UNDESA). (2005). Water for life,1-3.

United State Environmental Protection Agency (USEPA). (2005). Protecting Water Quality from Agricultural run-off, pp 1-5.

United State Environmental Protection Agency (USEPA). (2012). Drinking water standard and health advisories. $3-4$.

Water Quality Association. (2013). Technical fact sheet: Ammonia. International Headquarters \& Laboratory. Pp 1-2.

World Health Organization (WHO). (1999). International standard for drinking water, Vol. 5 pp 3-6. 